International Journal of Health Sciences
Available online at www.sciencescholar.us
Vol. 5 No. 2, August 2021, pages: $71-78$
e-ISSN: 2550-696X, p-ISSN: $2550-6978$
https://doi.org/10.29332/ijhs.v5n3.1187

\title{
Procalcitonin Levels Differences in Preeclampsia and Non- Preeclampsia
}

\author{
Nur Istiqamah Fatimah a, Sitti Wahyuni ${ }^{b}$, Sharvianty Arifuddin c \\ Manuscript submitted: 27 March 2021, Manuscript revised: 09 April 2021, Accepted for publication: 18 May 2021
}

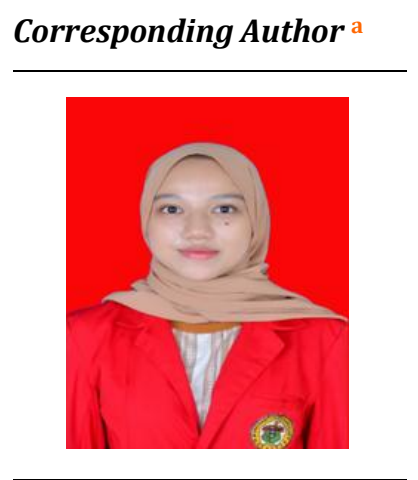

\section{Keywords}

preeclampsia;

procalcitonin;

track infection;

urinary;

\begin{abstract}
One of the main complications that cause maternal death is preeclampsia/eclampsia. Activation of the systemic inflammatory response is thought to play a role in the pathogenesis of preeclampsia. Urinary tract infections (UTI) can cause activation of the systemic inflammatory response so that it is considered capable of causing preeclampsia. Procalcitonin is known as a marker of infection and very stable in serum, so it is a promising biomarker in detecting UTI. The investigators intend to investigate the association between UTI and preeclampsia through the exploration of procalcitonin levels in preeclampsia and non-preeclampsia mothers. This study was a cross-sectional method, accident sampling technique. Respondents in this study amounted to 65 , preeclampsia criteria were 40 , and not preeclampsia was 25 . The results showed no relationship between urinary tract infections during pregnancy and preeclampsia $\mathrm{P}=0.074$. Even so, procalcitonin levels in preeclampsia mothers were found to be higher than mothers without preeclampsia, with a value of $\mathrm{P}=$ 0.005 . This means that the inflammation that occurs in preeclampsia mothers is not caused by urinary tract infections. It is hoped that further research can be carried out on the relationship between urinary tract infections and preeclampsia by using a larger sample.
\end{abstract}

International Journal of Health Sciences (C) 2021. This is an open access article under the CC BY-NC-ND license (https://creativecommons.org/licenses/by-nc-nd/4.0/).

\section{Contents}

Abstract...

1 Introduction

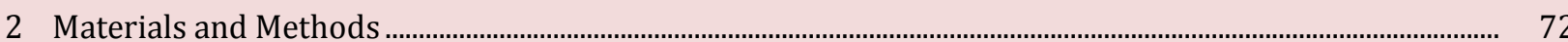

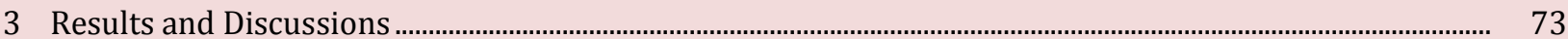

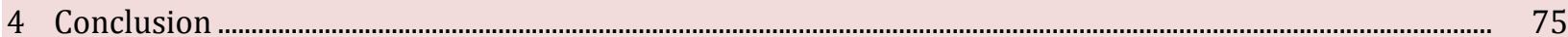

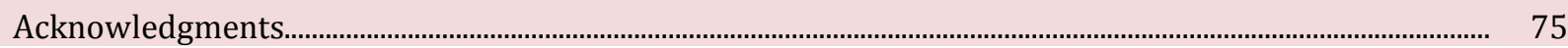

${ }^{a}$ Midwifery Postgraduate School, Hasanuddin University, Indonesia

${ }^{\text {b }}$ Department of Parasitology, Faculty of Medicine, Hasanuddin University, Indonesia

${ }^{\mathrm{c}}$ Department of Obstetrics and Gynecology, Faculty of Medicine, Hasanuddin University, Indonesia 


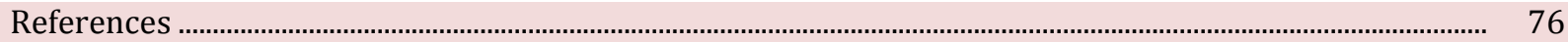

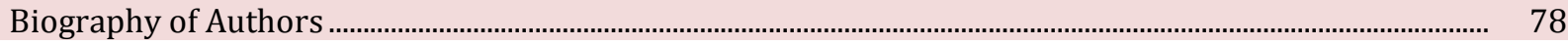

\section{Introduction}

Maternal Mortality Rate (MMR) is an indicator in measuring the health status and success of a country's services. One of the main complications that cause maternal death apart from postpartum hemorrhage, infection, complications of childbirth, and unsafe abortion is preeclampsia and eclampsia (World Health Organization, 2018). Preeclampsia is a condition where the occurrence of hypertension (blood pressure $\geq$ $140 / 90 \mathrm{~mm} \mathrm{Hg}$ ) and the presence of protein in urine specimens (300 $\mathrm{mg}$ or more over 24 hours), at gestational age $>20$ weeks and before 48 hours postpartum in pregnant wo men who previously normotensive (American College of Obstetricians and Task Force on Hypertension in Pregnancy, 2013).

According to WHO data, the incidence of preeclampsia in various parts of the world ranges from 5-7\% of all pregnancies, and there are 50,000 maternal deaths caused by preeclampsia and eclampsia worldwide each year (World Health Organization, 2018). Maternal mortality in Indonesia due to preeclampsia reaches $26.57 \%$ of 100,000 live births (Kemenkes, 2018). Based on the medical records of the Bahteramas Hospital of Southeast Sulawesi from January to October 2019, there were 83 cases of preeclampsia with six maternal deaths, including (Bahteramas Hospital Medical Records, 2019).

Excessive activation of the systemic inflammatory response is thought to play a fundamental role in the pathogenesis of preeclampsia. Inflammation-induced impairment of vascular endothelia is seen in women with preeclampsia (Lin et al., 2015; Pinto et al., 2017). The inflammatory response plays an essential role in the initiation and increase of uteroplacental atherosis so that infections that increase systemic inflammation can increase the risk of preeclampsia (Yan L, et al., 2018).

Urinary tract infections can cause activation of the systemic inflammatory response and endothelial damage, which in turn can lead to uteroplacental atherosis and placental hypoxia, which eventually progresses to preeclampsia (Yan L, et al., 2018). Research conducted in Tanzania in 2019 found a link between urinary tract infections and preeclampsia, as evidenced by high bacteriuria in pregnant women with preeclampsia and eclampsia compared to normal pregnant women (Kaduma et al., 2019). This contradicts the results reported by other investigators, and a controlled study found no association between urinary tract infections during pregnancy and the incidence of preeclampsia (Shamsi et al., 2010).

Procalcitonin (PCT) is a polypeptide precursor of calcitonin, widely used in clinical practice because it is known as a marker of infection (Meisner, 2014). Procalcitonin is one of several precursors of calcitonin that is involved in the body's immune system response, so it is called a hormone. The hormone properties of procalcitonin will respond to various kinds of inflammatory processes in the body including infection (Davies, 2015). Procalcitonin is very stable in serum so it is a good biomarker in detecting urinary tract infections (Hiremath \& Basu, 2017).

Management of preeclampsia can give better results if the cause is known as early as possible (Rehfeldt et al., 2018). Seeing the link between urinary tract infections and the incidence of preeclampsia and the link between procalcitonin and urinary tract infections, the researchers aimed to see the differences in procalcitonin levels in preeclamptic and non-preeclamptic mothers (Bellos et al., 2020).

\section{Materials and Methods}

This research was a cross-sectional method with an accident sampling technique. The study was conducted at the Lepo - Lepo Public Health Center and the Aliyah 2 Kendari Hospital in October 2020 - February 2021 and has received an ethical approval recommendation with the protocol number UH20090504. Measurement of procalcitonin levels was carried out at the Hasanuddin University Educational Hospital Laboratory using the Enzyme-Linked Immunosorbent Assay (ELISA) method, which was conducted in February 2021. Determination of the sample based on accident sampling, drawing the number of samples using the Harry King nomogram formula. The number of samples in this study amounted to 40 preeclampsia and 25 nonpreeclampsia mothers who met the inclusion criteria. Pregnant women who took antibiotics and 
corticosteroids, women with a history of premature rupture of membranes, liver problems, diabetes mellitus, or had multiple pregnancies were excluded from the study because they could cause an increase in procalcitonin levels. Demographic data of respondents were obtained using a questionnaire. Preeclampsia status is obtained through measurement of blood pressure and urine protein tests that examine procalcitonin levels used the ELISA (Enzyme-Linked Immunosorbent Assay) method. Data were analyzed using chi-square and Mann-Whitney tests with a significant level of $\alpha=0.05$.

\section{Results and Discussions}

Table 1

Characteristics of respondents

\begin{tabular}{|c|c|c|c|c|c|}
\hline \multirow{3}{*}{ Categories } & & \multicolumn{2}{|c|}{ Preeclampsia Status } & \multirow[t]{2}{*}{ Total } & \multirow{3}{*}{$P$-value } \\
\hline & & \multirow{2}{*}{$\begin{array}{l}\text { Yes } \\
\mathrm{N}=40(\%)\end{array}$} & No & & \\
\hline & & & $\mathrm{N}=25(\%)$ & $\mathrm{N}=65(\%)$ & \\
\hline \multirow[t]{2}{*}{ Age } & $<20$ or $>35$ th & $15(75.0 \%)$ & $5(25.0 \%)$ & $20(100 \%)$ & \multirow{2}{*}{0,173} \\
\hline & $20-35$ th & $25(55.6 \%)$ & $20(44,4 \%)$ & $45(100 \%)$ & \\
\hline \multirow{2}{*}{ Gravida } & Primigravida & $16(57.1 \%)$ & $12(42.9 \%)$ & $28(100 \%)$ & \multirow{2}{*}{0,610} \\
\hline & Multigravida & $24(65 \%)$ & $13(35 \%)$ & $34(100 \%)$ & \\
\hline \multirow{3}{*}{ Gestational } & 20-27 week & $20(59 \%)$ & $14(41 \%)$ & $34(100 \%)$ & \multirow[t]{3}{*}{0.799} \\
\hline & $>28$ week & $20(65 \%)$ & $11(35 \%)$ & $31(100 \%)$ & \\
\hline & Positive 2 & $2(100 \%)$ & 0 & $2(100 \%)$ & \\
\hline \multirow[t]{3}{*}{ Nitrit } & Positive 1 & $20(95 \%)$ & $1(5 \%)$ & $21(100 \%)$ & \multirow[t]{3}{*}{$<0.001$} \\
\hline & Negative & $24(57 \%)$ & $18(43 \%)$ & $42(100 \%)$ & \\
\hline & Positive 2 & $4(100 \%)$ & 0 & $4(100 \%)$ & \\
\hline \multirow{3}{*}{ Leucosit } & Positive 1 & $27(87 \%)$ & $4(3 \%)$ & $31(100 \%)$ & \multirow{3}{*}{$<0.001$} \\
\hline & Plus-neg & $9(50 \%)$ & $9(50 \%)$ & $18(100 \%)$ & \\
\hline & Negative & 0 & $12(100 \%)$ & $12(100 \%)$ & \\
\hline \multirow{2}{*}{$\begin{array}{l}\text { Symptoms of } \\
\text { urinary tract } \\
\text { infection }\end{array}$} & Yes & $30(90.9 \%)$ & $3(9.1 \%)$ & $33(100 \%)$ & \multirow[b]{2}{*}{$<0.001$} \\
\hline & No & $10(31.3 \%)$ & $22(68.7 \%)$ & $32(100 \%)$ & \\
\hline
\end{tabular}

${ }^{*}$ Chi-square

The table above shows that between the preeclampsia and non-preeclampsia groups, there were no significant differences in age, gravida, and gestation categories. However, nitrate levels, urinary leukocytes, and urinary tract infection symptoms differed between those with preeclampsia and non-preeclampsia.

Table 2

Comparison of procalcitonin levels in urinary track infection and non- urinary track infection mothers

\begin{tabular}{|c|c|c|c|}
\hline & & Procalcitonin contein $(\mathrm{Pg} / \mathrm{ml})$ & \multirow{2}{*}{ P-value } \\
\hline & & Median ( Min-Max) & \\
\hline \multirow{2}{*}{$\begin{array}{l}\text { urinary track } \\
\text { infection }\end{array}$} & Yes $(n=6)$ & $244.67(192.61-269.70)$ & \multirow[b]{2}{*}{0.482} \\
\hline & No $(\mathrm{n}=59)$ & 236.30 (171.92-434.98) & \\
\hline
\end{tabular}

*Uji mann-whitney

The results showed no significant difference between procalcitonin levels in urinary tract infections and nonurinary tract infections with P-value $=0.482$. The minimum and maximal values of procalcitonin levels in urinary tract infection mothers were $192.61-269.70 \mathrm{pg} / \mathrm{ml}$, while the minimum and maximum levels in mothers without urinary tract infections were $171.92-434.98 \mathrm{pg} / \mathrm{ml}$.

Fatimah, N. I., Wahyuni, S., \& Arifuddin, S. (2021). Procalcitonin levels differences in preeclampsia and non preeclampsia. International Journal of Health Sciences, 5(2), 71-78. https://doi.org/10.29332/ijhs.v5n3.1187 
Table 3

Comparison of procalcitonin levels in preeclampsia and non-preeclamptic mothers

\begin{tabular}{llll}
\hline & & Procalcitonin contein $(\mathrm{Pg} / \mathrm{ml})$ & P-value \\
\cline { 2 - 3 } Preeclampsia & Yes $(\mathrm{n}=40)$ & $241.34(171.92-434.98)$ & 0.005 \\
\cline { 2 - 3 } & No $(\mathrm{n}=25)$ & $227.78(175.92-268.07)$ & \\
\hline
\end{tabular}

*Uji Mann-Whitney

The results showed a significant difference between procalcitonin levels in preeclamptic and nonpreeclamptic mothers with a value of $\mathrm{P}=0.005$. The minimum and maximal values of procalcitonin levels in preeclamptic mothers are $171.92-434.98 \mathrm{pg} / \mathrm{ml}$, while the minimum and maximum levels in women without preeclampsia are $175.92-268.07 \mathrm{pg} / \mathrm{ml}$.

Table 4

Relationship between urinary tract infection and preeclampsia

\begin{tabular}{|c|c|c|c|c|}
\hline & & \multicolumn{2}{|c|}{ Preeclampsia Categories } & \multirow{3}{*}{$P$-value } \\
\hline & & Yes & No & \\
\hline & & $n=40(61.5 \%)$ & $\mathrm{n}=25(38.5 \%)$ & \\
\hline \multirow{2}{*}{ Urinary tract infection } & Yes $(n=6)$ & $6(100 \%)$ & 0 & \multirow{2}{*}{0.074} \\
\hline & No $(n=59)$ & $34(57.6 \%)$ & $25(42.4 \%)$ & \\
\hline
\end{tabular}

*Uji chi-square.

The table above shows no significant relationship between urinary tract infections and urinary tract infection symptoms in pregnant women with preeclampsia incidence with $\mathrm{P}<0.074$. Diagnosis of urinary tract infection is obtained from examination of urinary nitrite and leukocytes.

\section{Discussion}

In this study, there was no association between maternal age and the incidence of preeclampsia. Respondents are aged <20 years or $>35$ years were 22 respondents while respondents aged 20-35 years were 43 respondents. This may be due to the insufficient sample size or because the majority of pregnancies in Kendari City occur in the age range of 20-35 years (Tan et al., 2014).

Maternal age is one of the risks of hypertension in pregnancy. In a secondary analysis of HYPITAT-II data, the risk of conceiving increased with increasing maternal age (Broekhuijsen et al., 2015). In late pregnancy, there is a decrease in vascular adaptation and an increase in afterload instead of hemodynamic adaptation during pregnancy, where afterload is generally decreased. Pregnant women aged less than 20 years are also at risk of developing preeclampsia due to failure of trophoblast invasion, which causes maladaptation that triggers the development of preeclampsia (Kumari et al., 2016).

Characteristics of respondents based on gravida, in this population it was found that more multigravidas had preeclampsia, namely 34 respondents and 28 primigravidas. Multigravida mothers ( $>3$ times delivery) are at risk of developing preeclampsia due to decreased reproductive system function. Characteristics of respondents based on gestational age, we found preeclampsia occurred at 20-27 weeks of gestation and $>28$ weeks (Van Helden \& Weiskirchen, 2015). Gestational age is closely related to preeclampsia because preeclampsia is a specific syndrome in pregnancy that occurs after 20 weeks of gestation in women who were previously normotensive. Based on the respondent's gestational age characteristics, it can be ascertained that the high blood pressure experienced by the respondent is correct because of preeclampsia because everything occurs at $>20$ weeks of gestation (Dockree et al., 2021).

In this study population, researchers found no correlation between urinary tract infections and the incidence of preeclampsia. The increase in procalcitonin levels may be caused by factors other than urinary tract infections (Yalman et al., 2021). Diagnosis of urinary tract infection was obtained from anamnesis using a questionnaire and the results of examining urinary leucocytes and nitrites. Urinary tract infection is an 
infection that often occurs in pregnancy due to changes in physiological adaptations, where there is an increase in plasma volume, which causes a decrease in urine concentration, thereby facilitating the development of bacteria (Michelim et al., 2016).

Urinary tract infections (UTIs) are thought to increase the risk of preeclampsia because they can trigger an increased activation of the systemic inflammatory response (Chaemsaithong et al., 2020). Excessive activation of the systemic inflammatory response is thought to have an essential role in the initiation and increase of uteroplacental atherosis, which is directly related to the pathophysiology of preeclampsia so that any factors that can trigger an increase in the systemic inflammatory response can contribute to the incidence of preeclampsia (Prawirohardjo, 2014). Other studies have also reported that pregnant women who experience urinary tract infections have a high risk of preeclampsia (Easter et al., 2016). Research conducted in Iran also reported that the first-trimester pregnancy accompanied by urinary tract infections is closely related to the incidence of preeclampsia (Zahedkalaei et al., 2020). Therefore, early treatment and prevention of urinary tract infections in pregnant women are expected to reduce the possibility of preeclampsia.

Procalcitonin is generally produced through two alternative mechanisms, namely through direct pathways induced by a bacterial endotoxin or other toxic metabolites from microbes (such as DNA, fimbriae, or peptidoglycan) and indirect pathways induced by various pro-inflammatory cytokines such as TNF- $\alpha$, IL $-1 \beta$, IL-6, and IL-8 (Matwiyoff et al., 2012). Several studies have reported higher levels of inflammatory cytokines in mothers with preeclampsia compared to normal pregnancies (Do et al., 2021). For example, IL-6 and TNF- $\alpha$, which are inflammatory mediators associated with endothelial damage and oxidative stress, were found to be elevated in preeclamptic patients (Redman et al., 2015). Increased local and systemic pro-inflammatory cytokine production increases macrophage procalcitonin production; this triggers a self-amplifying loop, in which procalcitonin induces increased production of pro-inflammatory cytokines by macrophages. Procalcitonin by itself is capable of inducing direct damage to the endothelium and resulting in worsening endothelial function, which is pathophysiological of preeclampsia (Matwiyoff et al., 2012). A study by Reihane Jannesari et al. comparing two inflammatory markers, one of which is procalcitonin, in pregnant women with preeclampsia and women with normal pregnancies, showed that procalcitonin levels were higher in pregnant women with preeclampsia compared to normal pregnant women (Jannesari \& Kazemi, 2017). Although this study population did not find high procalcitonin levels, it was found that procalcitonin levels in those with preeclampsia were higher than those without preeclampsia (Birdir et al.,2020).

\section{Conclusion}

In this study, there is no association of urinary tract infections in pregnancy with the incidence of preeclampsia. However, levels of procalcitonin were found to be higher in preeclampsia mothers, which indicates that the inflammation that occurs in preeclampsia women is not caused by urinary tract infections.

\section{Acknowledgments}

The completion of this research cannot be separated from the support of various parties. Researchers specifically express their deepest gratitude to the Head of Postgraduate School Hasanuddin University, Aliyah II Hospital in Kendari, Lepo-Lepo Public Health Center in Kendari, All Respondents and community, and all those who have helped provide suggestions and input as well as an encouragement both moral and material.

Fatimah, N. I., Wahyuni, S., \& Arifuddin, S. (2021). Procalcitonin levels differences in preeclampsia and non preeclampsia. International Journal of Health Sciences, 5(2), 71-78. https://doi.org/10.29332/ijhs.v5n3.1187 


\section{References}

American College of Obstetricians and Gynecologists. (2013). Hypertension in pregnancy. Report of the American College of Obstetricians and Gynecologists' task force on hypertension in pregnancy. Obstetrics and gynecology, 122(5), 1122-1131.

Bellos, I., Pergialiotis, V., Papapanagiotou, A., Loutradis, D., \& Daskalakis, G. (2020). Association between serum copeptin levels and preeclampsia risk: A meta-analysis. European Journal of Obstetrics \& Gynecology and Reproductive Biology. https://doi.org/10.1016/j.ejogrb.2020.04.051

Birdir, C., Fox, L., Droste, L., Frank, M., Fryze, J., Enekwe, A., ... \& Gellhaus, A. (2020). MR-proANP, a cardiovascular biomarker to predict late-onset preeclampsia and intrauterine growth-restricted fetuses. Pregnancy Hypertension, 22, 54-58. https://doi.org/10.1016/j.preghy.2020.07.004

Broekhuijsen, K., van Baaren, G. J., Van Pampus, M. G., Ganzevoort, W., Sikkema, J. M., Woiski, M. D., ... \& HYPITAT-II study group. (2015). Immediate delivery versus expectant monitoring for hypertensive disorders of pregnancy between 34 and 37 weeks of gestation (HYPITAT-II): an open-label, randomised controlled trial. The Lancet, 385(9986), 2492-2501.

Chaemsaithong, P., Sahota, D., \& Poon, L. C. (2020). First-trimester preeclampsia screening and prediction. American Journal of Obstetrics and Gynecology. https://doi.org/10.1016/j.ajog.2020.07.020

Davies, J. (2015). Procalcitonin. Journal of clinical pathology, 68(9), 675-679.

Do, S. C., Miller, H., Leonard, S. A., Datoc, I. A., Giesen, A. I., Kappagoda, S., ... \& Aziz, N. (2021). Lactate and procalcitonin levels in peripartum women with intraamniotic infection. American Journal of Obstetrics \& Gynecology MFM, 3(4), 100367. https://doi.org/10.1016/j.ajogmf.2021.100367

Dockree, S., Brook, J., James, T., Shine, B., \& Vatish, M. (2021). A pregnancy-specific reference interval for procalcitonin. Clinica Chimica Acta, 513, 13-16. https://doi.org/10.1016/j.cca.2020.12.007

Easter, S. R., Cantonwine, D. E., Zera, C. A., Lim, K. H., Parry, S. I., \& McElrath, T. F. (2016). Urinary tract infection during pregnancy, angiogenic factor profiles, and risk of preeclampsia. American journal of obstetrics and gynecology, 214(3), 387-e1.

Hiremath, R. S., \& Basu, A. (2017). Role of procalcitonin and C-reactive protein in urinary tract infection diagnosis in adults. International Journal of Advances in Medicine, 4(2), 417.

Jannesari, R., \& Kazemi, E. (2017). Level of high sensitive C-reactive protein and procalcitonin in pregnant women with mild and severe preeclampsia. Advanced biomedical research, 6 .

Kaduma, J., Seni, J., Chuma, C., Kirita, R., Mujuni, F., Mushi, M. F., ... \& Mshana, S. E. (2019). Urinary tract infections and preeclampsia among pregnant women attending two hospitals in Mwanza City, Tanzania: A 1: 2 Matched case-control study. BioMed research international, 2019.

Kemenkes RI. (2018). Hari Hipertensi Dunia 2019: “Know Your Number, Kendalikan Tekanan Darahmu dengan CERDIK."', Kementrian Kesehatan Republik Indonesia.

Kumari, N., Dash, K., \& Singh, R. (2016). Relationship between Maternal Age and Preeclampsia. IOSR Journal of Dental and Medical Sciences, 15(12), 55-7.

Lin, S., Leonard, D., Co, M. A., Mukhopadhyay, D., Giri, B., Perger, L., ... \& Uddin, M. N. (2015). Pre-eclampsia has an adverse impact on maternal and fetal health. Translational Research, 165(4), 449-463. https://doi.org/10.1016/j.trsl.2014.10.006

Matwiyoff, G. N., Prahl, J. D., Miller, R. J., Carmichael, J. J., Amundson, D. E., Seda, G., \& Daheshia, M. (2012). Immune regulation of procalcitonin: a biomarker and mediator of infection. Inflammation Research, 61(5), 401-409.

Meisner, M. (2014). Update on procalcitonin measurements. Annals of laboratory medicine, 34(4), 263.

Michelim, L., Bosi, G. R., \& Comparsi, E. (2016). Urinary tract infection in pregnancy: review of clinical management. J Clin Nephrol Res, 3(1), 1030.

Pinto, F., Suwiyoga, I. K., Widiana, I. G. R., \& Yasa, I. W. P. S. (2017). Health behavior and status related to mother's death in Timor-Leste. International Research Journal of Engineering, IT and Scientific Research, 3(4), 57-65.

Prawirohardjo, S. (2014). Ilmu Kebidanan Sarwono Prawirohardjo. Jakarta: PT. Bina Pustaka Sarwono Prawirohardjo.

Redman, C. W., Sargent, I. L., \& Taylor, R. N. (2015). Immunology of normal pregnancy and preeclampsia. In Chesley's hypertensive disorders in pregnancy (pp. 161-179). Academic Press. 
Rehfeldt, M., Eklund, E., Struck, J., Sparwasser, A., O'Brien, B., Palomaki, G. E., ... \& Lambert-Messerlian, G. (2018). Relaxin-2 connecting peptide (pro-RLX2) levels in second-trimester serum samples to predict preeclampsia. Pregnancy hypertension, 11, 124-128. https://doi.org/10.1016/j.preghy.2017.11.001

Shamsi, U., Hatcher, J., Shamsi, A., Zuberi, N., Qadri, Z., \& Saleem, S. (2010). A multicentre matched case-control study of risk factors for preeclampsia in healthy women in Pakistan. BMC women's health, 10(1), 1-7..

Tan, K. H., Tan, S. S., Sze, S. K., Lee, W. K. R., Ng, M. J., \& Lim, S. K. (2014). Plasma biomarker discovery in preeclampsia using a novel differential isolation technology for circulating extracellular vesicles. American journal of obstetrics and gynecology, 211(4), 380-e1. https://doi.org/10.1016/j.ajog.2014.03.038

van Helden, J., \& Weiskirchen, R. (2015). Analytical evaluation of the novel soluble fms-like tyrosine kinase 1 and placental growth factor assays for the diagnosis of preeclampsia. Clinical biochemistry, 48(16-17), 1113-1119. https://doi.org/10.1016/j.clinbiochem.2015.06.020

World Health Organization. (2018). WHO expert consultation on rabies: third report (Vol. 1012). World Health Organization.

Yalman, M. V., Madendag, Y., Sahin, E., Madendag, I. C., Sahin, M. E., Acmaz, G., ... \& Muderris, I. I. (2021). Effect of preeclampsia and its severity on maternal serum NGAL and KIM-1 levels during pregnancy and the postpregnancy period. European Journal of Obstetrics \& Gynecology and Reproductive Biology, 256, 246-251. https://doi.org/10.1016/j.ejogrb.2020.11.040

Yan, L., Jin, Y., Hang, H., \& Yan, B. (2018). The association between urinary tract infection during pregnancy and preeclampsia: A meta-analysis. Medicine, 97(36).

Zahedkalaei, A. T., Kazemi, M., Zolfaghari, P., Rashidan, M., \& Sohrabi, M. B. (2020). Association Between Urinary Tract Infection in the First Trimester and Risk of Preeclampsia: A Case-Control Study. International Journal of Women's Health, 12, 521.

Fatimah, N. I., Wahyuni, S., \& Arifuddin, S. (2021). Procalcitonin levels differences in preeclampsia and non preeclampsia. International Journal of Health Sciences, 5(2), 71-78. https://doi.org/10.29332/ijhs.v5n3.1187 


\section{Biography of Authors}

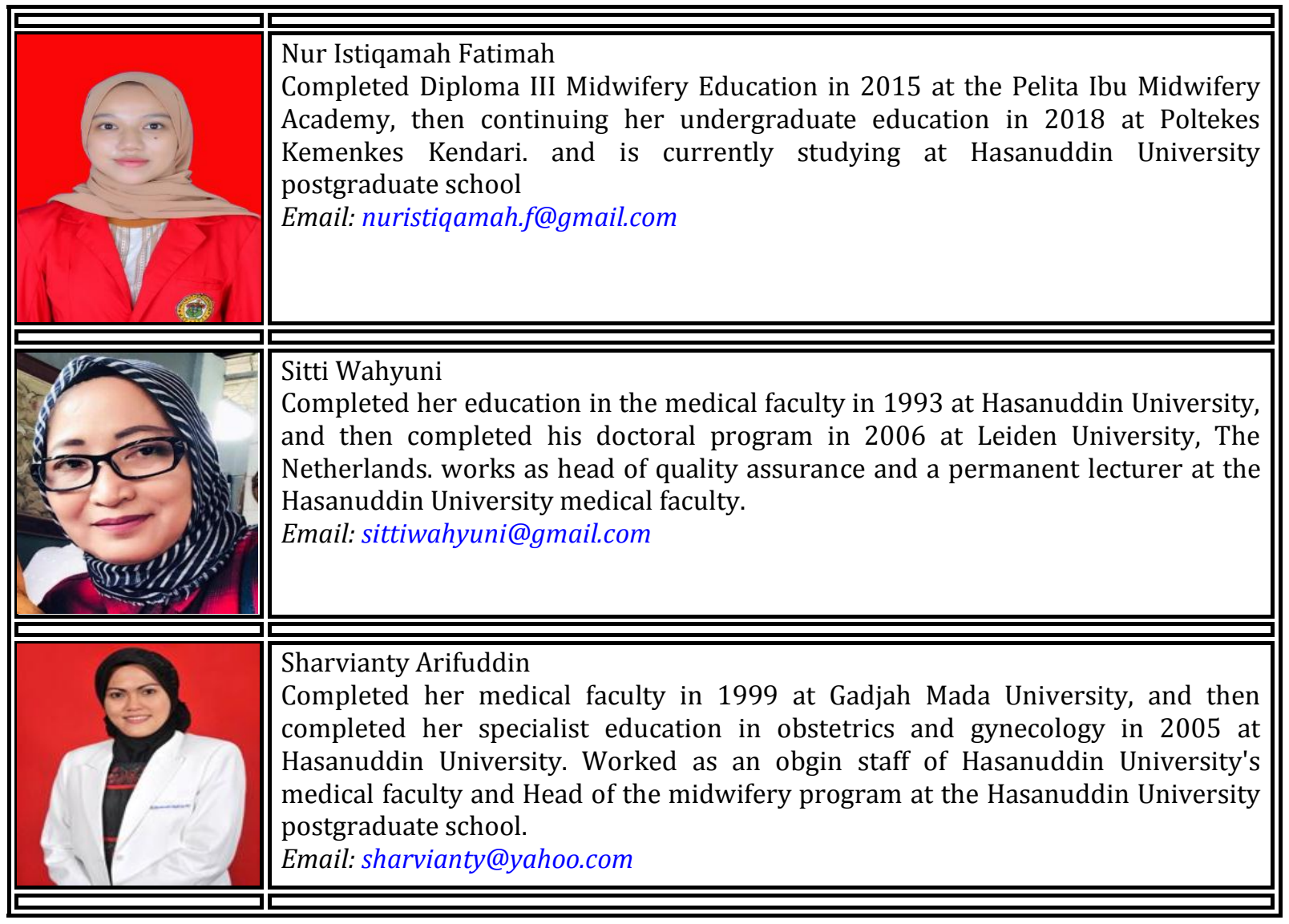

